\title{
NEWS FOR THE MEMBERS
}

THE MIDDLE EAST EDUCATIONAL TRUST, INC, has announced that the Ethnic Heritage Division of the Office of International Education of the U.S. Department of Health, Education and Welfare has awarded the Trust a grant for the production and distribution of a film on the Arab-Americans and their legacy to the U.S. The Arab-American Ethnic Heritage $f i l m$ is designed to supplement educational materials in secondary schools and other programs of continuing education and for use on educational television. Its purpose is to fill a major gap in studies of American heritage and to inform students and the public about this little-known ethnic community in the U.S. The 28 minute film will focus on how immigrants from the Arab countries of the Eastern Mediterranean became Americans, surveying their experience from departure from the homeland to the present day.

The Arab civilization film project will address itself to the results of a national survey made by MESA (Image Report) conducted in secondary schools to determine the extent of knowledge conveyed by American schools. The survey concluded that most current textbooks "erred in content and perpetuated stereotypes."

MEET plans to become a multimedia resource for all levels of American education. Among the members of the Board are Edmond Howar of Washington, D.C., Dr。 Joseph Malone, National War College, Hugh Auchincloss, Jr., of N.Y.C. Members of the Advisory Council include: Michael Suleiman, Kansas State; Ayad al-Qazzaz, California State; Mounir Farah, Danbury, Conn.; Evelyn Menconi, Dorchester, Mass.; Robert A. Metry, Louisville, Ky。; Abdul A. Said, American University; Dale Tahtinen, American Enterprise Institute.

The Middle East Educational Trust, a Washington-based non-profit, non-political corporation, is engaged in researching, preparing, producing and disseminating educational materials on the history, culture and civilization of the peoples of the Middle East.

Requests for additional information should be addressed to:

Director, Community and Corporate Relations, The Middle East Trust, Inc., 2042 Peach Orchard Drive, Falls Church, Virginia 22043.

HEBREW STUDIES ANNUAL, a new journal, will be published by the Division of Hebrew Language and Literature of the Ohio State University in the Fall of 1977. Articles submitted to the Annual should deal with problems in these areas: Bible, Herbew language, Hebrew literature, methodology of teaching Hebrew on the college level.

The Editorial Board will be: Yehiel Hayon (Editor), Rebuben Ahroni, David Golomb, and David Salczer. The deadline for submitting articles for the 1977 edition is March 1, 1977. Articles and inquiries should be addressed to: Yehiel Hayon, Editor, Hebrew Studies Annual, Division of Hebrew, the Ohio State University, 1841 Millikin Rd., Columbus, Ohio 43210 .

The International Journal of Middle East Studies is now indexed in Combined Retrospective Index sets (CRIS). Free brochures describing the project can be obtained by writing to: William Buchanan, Carroliton Press, Inc., 1911 Fort Myer Drive, Arlington, Virginia 22209.

A catalogue of raxe and out of print books on Greece, Cyprus and Turkey is available from W.B. O'Net1l, Old and Rare Books, 11609 Hunters Green Court, Reston, Virginia 22091. 
NATIONAL ENDOWMENT FOR THE HUMANITIES, Division of Research Grants announces an experimental program to support translations into English of major works in foreign languages and invites the submission of proposals for that purpose. Texts from any discipline relevant to humanistic scholarship are eligible. Preference will be given to translations of primary sources from pre-modern periods but outstanding secondary works of particular historical or cultural importance will also be considered. Although projects for translation from all languages are eligible, the Division has been alerted to particularly pressing needs for translations from the Chinese and the major Islamic languages, Arabic, Persian and Turkish.

The application should include: 1) a description and summary of the contents of the text proposed for translation and a statement concerning the status of the text - does the text exist in a definitive edition? 2) A statement concerning the significance of the work, its place in its own intellectual tradition, and its importance for scholars who do not command the language of the original. 3) A brief description of the applicant's linguistic competence and general scholarly expertise. 4) A discussion of the particular problems connected with the proposed translation and how these are to be dealt with. In addition to questions of translation, this discussion should include details concerning the scholarly apparatus-notes, glossaries, etc--and an outline of the introduction which will procede the translation. 5) The applicant should submit a sample translation (with notes) of approximately five typewritten pages. A photostat of the original from which the sample was translated should accompany the application.

Funding: A single application may request support for up to 3 years. Deadline: The first deadline for submitting proposals in final form will be April 1, 1977. Decisions will be available in september 1977. Inquiries: J.Leeds Barrol1, Deputy Director of the Division, and Susan Mango, Division of Research Grants, Mail Stop 350, NEH, 806 15 th Street N.W。, Washington, D。C. 20506 .

CANADIAN REVIEW OF STUDIES IN NATIONALISM is a scholarly journal dedicated to the comparative study of nationalism as a force in any area of the world. The REVIEW solicits subscriptions and inquiries as well as manuscripts in English, French, and German. A semi-annual publication, CRSN will also provide an annual annotated bibliographic supplement of literature relating to nationalism. Subscription per annum: $\$ 9.00$ - student rate $-\$ 5.00$. For further information please write to: Thomas Spira, Editor, Dept of History, University of $P$ Prince Edward Island, Charlottetown, P.E.I., Canada.

SEMINAR: A regiona1 Middle East/North Africa seminar is being organized in the southeastern United States. Interested persons in al1 disciplines and fields of employment in Georgia, South Carolina, North Carolina, eastern Tennessee, eastern Kentucky, and Virginia (except the Washington, D.C. suburbs) should contact Jerome B Weiner, Dept of History, Old Dominion University, Norfolk, Virginia 23508 for further information.

MIDDLE EAST RESEARCH GROUP - Middle East anthropologists who convened at the 1976 American Anthropology Association Annual meeting are starting a newsletter. A11 persons interested in the Middle East are invited to join this communications network. Send name, address, theoretical and geographic area(s) of interest, and $\$ 2.00$ for mailing costs to: Suad Joseph, Department of Anthropology, University of California, Davis, California 95616. The first newsletter will come out in late February. It will include a directory of these names and interests, a summary of the workshop luncheon on Critical Anthropology of the Middle East and the organizational meetings, and announcements any participants wish to send in. 
MIDDLE EAST STUDY TOUR is being sponsored by the Miami University, oxford, Ohio. The tour include visits to archaeological sites, museums, places of historical, religious and social significance. Graduate and undergraduate levels will participate in an interdisciplinary survey of the area. The special topics will be: "The Middle Eastern City." Hellenism in the Middle East," and "Four Middle Eastern Religions." The estimated cost, in addition to registration for 6 hours credit at Miami University, is $\$ 1960$. This includes air fare from New York, ground transportation, admission fees and "half board." Application deadline is March 15, 1977. For additional information contact, Dr. Carl Jantzen, Dept of Sociology and Anthropology (513-529-2628), or Dr. Newell Booth, Dept of Religion (513-529-4828), Miami University, Oxford, Ohio 45056 .

The MIDDLE EAST INSTITUTE is offering a non-credit Persian language program. The basic courses stress usage of practical, conversational Persian, while advanced and literary courses are available to the student of Iranian literature and culture. For further information contact, the Director, Persian Language Program, The Middle East Institute, 1761 N Street, N.W., Washington, D.C. 20036.

JERUSALEM ARCHIVES is a retrieval and research service that provides complete information in English from the archives of "The Jerusalem post" and other sources. The service can be obtained by individual orders or by annual subscription. Further information - Jerusalem Archives, 110 East 59th Street, Suite 1100, New York, New York 10022.

Gamal Mohamed Ahmad, author of THE INTELLECTUAL ORIGINS OF EGYPTIAN NATIONALISM and until recently, Foreign Minister of the Sudan, will be a visiting fellow at Harvard from May through June 1977. A lecture tour is being arranged for late May/early June. Those interested in having Mr Ahmad speak should contact Ms. Barbro Ek, Center for Middle Eastern Studies, Harvard University, Cambridge, Mass. 02138.

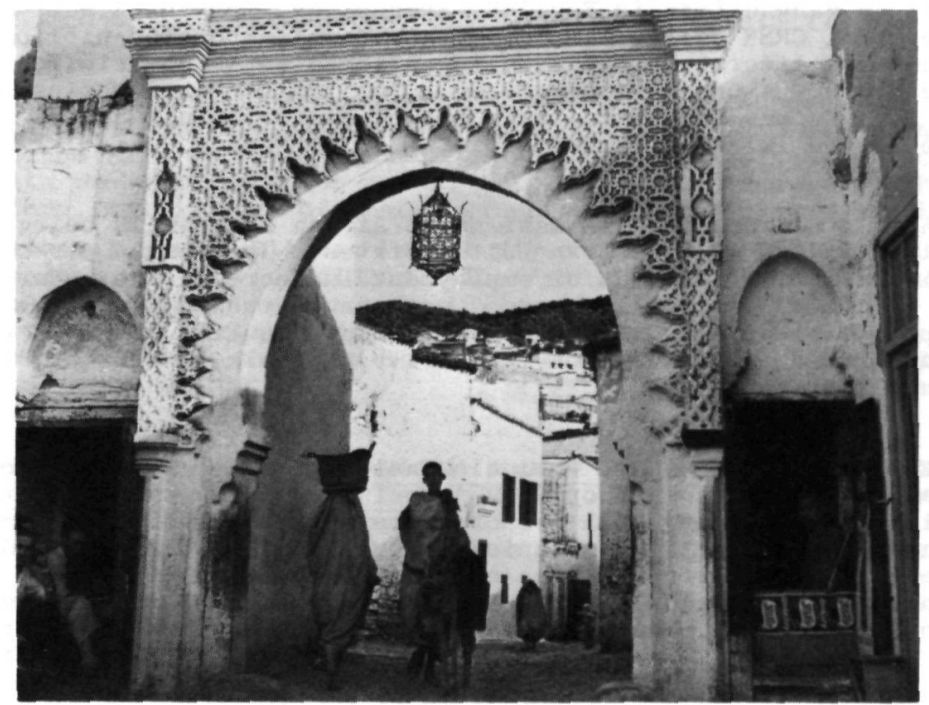

Photo courtesy of Moroccan Tourist Board. 